\title{
Jus Cogens: \\ Problem of the Role in Treaty Interpretation*
}

\author{
Svitlana Karvatska ${ }^{1}$ \\ Yuriy Fedkovych Chernivtsi National University, Ukraine
}

d.

10.15408/jch.v9i2.22235

\begin{abstract}
Due to their specific legal nature, the jus cogens rules occupy a special place and have conceptual significance in international law system in the vein that their non-compliance may, in fact, sabotage foundations of the international legal system based on states consent. Since the entry into force of the VCLT, jus cogens concept in international law has moved closer to international legal practice. A paradoxical situation exists - jus cogens concept in international law is generally accepted, there is also a normatively established definition of such a rule, but its specific framework and content remain unclear. The ICJ has repeatedly addressed the issue of jus cogens norms, but a detailed concept on jus cogens has not been formed. It is analyzed that the problem of establishing jus cogens is difficult to solve in abstractio. The reason lies not only in the absence of a single official list of norms jus cogens - the criteria for including norms in such a list are not defined. Opinions of representatives of the doctrine and the international judiciary on this issue differ significantly. Addressing the problem of the role and significance of jus cogens, general international law imperative rules, for the observance and interpretation of treaties, it should be noted that treaties are to be interpreted in a format compatible with the imperative norms. The considerations presented in the research indicate a special, if not decisive, role in the observance of jus cogens in treaties interpretation.
\end{abstract}

Keywords: International Law; VCLT; Treaties; Imperative Rules

* Received: March 18, 2021, revised: April 18, 2021, accepted: June 18, 2021, Published: 31 August, 2021.

1 Doctor in Law (LL.D), Associate Professor, Department of European Law and Comparative Law Studies, Yuriy Fedkovych Chernivtsi National University, Ukraine. ORCID: https://orcid.org./0000-00019948-4866

Corresponding author: svitlana.karvatska288822@gmai.com 


\title{
Jus Cogens: \\ Masalah Peran dalam Interpretasi Perjanjian
}

\begin{abstract}
Abstrak
Aturan Jus Cogens menempati tempat khusus dan memiliki makna konseptual dalam sistem hukum internasional dikarenakan sifat hukumnya yang spesifik, selain karena ketidakpatuhannya dapat menyabot fondasi sistem hukum internasional berdasarkan persetujuan negara. Sejak berlakunya VCLT, konsep Jus Cogens dalam hukum internasional semakin mendekati praktik hukum internasional. Situasi paradoks terjadi konsep Jus Cogens dalam hukum internasional diterima secara umum. Ada juga definisi yang ditetapkan secara normatif dari aturan semacam itu, tetapi kerangka kerja dan isinya yang spesifik masih belum jelas. ICJ telah berulang kali membahas masalah norma Jus Cogens, tetapi konsep rinci tentang Jus Cogens belum terbentuk. Dianalisis bahwa masalah pembentukan Jus Cogens sulit dipecahkan secara abstrak. Alasannya tidak hanya terletak pada tidak adanya satu daftar resmi norma Jus Cogens - kriteria untuk memasukkan norma dalam daftar tersebut tidak didefinisikan. Pendapat perwakilan doktrin dan peradilan internasional tentang masalah ini berbeda secara signifikan. Mengatasi masalah peran dan pentingnya Jus Cogens, aturan umum hukum internasional imperatif, untuk ketaatan dan interpretasi perjanjian. Perlu dicatat bahwa perjanjian harus ditafsirkan dalam format yang kompatibel dengan norma-norma imperatif. Pertimbangan yang disajikan dalam penelitian ini menunjukkan peran khusus, jika tidak menentukan, dalam ketaatan Jus Cogens dalam interpretasi perjanjian.
\end{abstract}

Kata kunci: Hukum Internasional; VCLT; Perjanjian; Aturan Imperatif

\section{Jus Cogens, \\ Проблема Роли В Толковании Договора}

\begin{abstract}
Аннотация
Нормы jus cogens вследствие своей специфрической правовой природы занимают особое место, имеют концептуальное значение в системе международного права в том смысле, что их несоблюдение может фактически подорвать основы международной правовой системы, которая опирается на согласие государств. Со времени своего включения в Венскую конвенцию о праве международных договоров 1969 г., концепция международного права jus cogens подошла к международной юридической практике. Доказано, что имеет место парадокс - концепция jus cogens в международном праве общепринятая, также существует нормативно-закрепленное понятие такой нормы, при этом ее рамки и содержание остаются неточными. MC OOH неоднократно касался проблематики норм јus cogens, однако не дал системного видения данного вопроса. Проблему определения jus cogens pешить in abstracto сложно. Причина не только в отсутствии единого официального перечня норм jus cogens - не определены критерии включения норм в такой перечень. Мнения представителей доктрины и международного судейского корпуса по этому поводу существенно различаются. Приведенные в исследовании соображения свидетельствуют об особой, если не решающей, роли jus cogens в процессе интерпретации международных договоров.
\end{abstract}

Ключевые слова: Jus cogens, международное право, интерпретация международных договоров, ВКПМД 


\section{A. INTRODUCTION}

As an object of international legal research, jus cogens rules, due to their specific legal nature, occupy a special place in international law system. The question of jus cogens' legal nature has always been of scientific interest, given the nature of these norms as imperative fundamental international law principles. The imperative nature of such norms of law is essential for understanding the nature of jus cogens rules.

Jus cogens - an imperative rule of general international law adopted and recognized by the global community as a whole as a rule from which deviation can be made and which can be changed only by another international law rule of a similar character (Linderfalk: 2011, 377). The jus cogens concept is an unchanging foundation of the international legal order designed to protect the fundamental interests and values of the global community of states, which is supported by the global community as a whole (Butkevych: 2015, 12).

The concept of jus cogens has a conceptual meaning in the sense that its noncompliance may, in fact, sabotage foundations of an international legal system found on states consent (Bossuyt: 2005, 72-98). Despite the fact that the doctrine of international public order concept is criticized for its domestic nature and more theoretical than practical significance, it should be recognized that the idea of the international order is an essential feature of modern international law (Lauterpach: 1958). It is essential that jus cogens are immediately linked with the prohibition of concluding treaties that violate human rights and reflect the basic international law principles, such as a sovereign equality principle or the principle of selfdetermination.

\section{B. METHODS}

One of the important stages of the research was to determine its methodology, based on a broad approach to analyzing the object and the subject. The approach foresaw the use of a wide range of philosophical, general scientific, special scientific, and legal methods. The epistemological method revealed the jus cogens nature and significance in treaties interpretation. The historical method allowed us to trace the evolution of the formation of jus cogens notion in international law.

The author's conclusions are based on the results of a scientific analysis of the significant law enforcement practice of international courts (ICJ, ECtHR), carried out using the empirical method of research. An important methodological principle was the logical method of clear construction of the study: the logical sequence of studying independent but inextricably linked issues, allowed to reach a qualitatively new level 
of reflection of the subject of study and fully solve the objectives of the study.

The synergetic method as a qualitatively new approach in scientific cognition allowed to determine basic principles and patterns of functioning of interpretation subjects and the formation of their interpretive methodology. Various legal research methods were widely used in the analysis. In particular, the formal-legal method was used to analyze jus cogens functions. The comparative law method allowed to conduct a comparison application of $j u s$ cogens application in specific international law areas.

\section{RESULT AND DISCUSSION}

\section{Jus cogens: nature, notion, basic approaches}

In the international law theory, three main approaches to studying jus cogens have been formed: the notion of natural law, the notion of positivism, and the notion of international public order. Proponents of the natural law approach see the nature of the imperative character of jus cogens rules in the idea of a higher law, prevailing over other norms and going beyond the state's consent or will (Dörr, Schmalenbach: $2018,903,908)$. At the same time, representatives of the positivist school assume the existence of any international law rules, including jus cogens, only as a consequence of the state's consent to their legal force, although the representatives of extreme positivism - normativism (G. Kelzen, G. Schwarzenberger, etc.) reject the existence of jus cogens rules as rules, the application of which cannot be ruled out with the consent of states (Kelzen: 2004, 253-255).

Given the importance of the values that this rule protects, jus cogens was recognized as the rule, as noted by prof. Zadorozhniy O. V., $(2015,13)$ which in the hierarchy of international law rules resides at a higher level than the rules of contractual and customary law. No rule of either international or national law can be hierarchically higher than jus cogens rules (Grushko: 2018, 241). In other words, jus cogens should be considered as the international law basis.

However, despite considerable interest, no consensus has yet been reached in international doctrine and practice on the theoretical basis of the concept of jus cogens norms; moreover, in the process of their practical application, new, to some extent even contradictory, provisions are revealed. This explains the interest and consideration by the International Law Commission (ILC) during 2015-2017 of the jus cogens issue and the inclusion of the issue "Identification of customary international law" on the agenda of the ILC during the Seventieth Session of the UNGA. At this session, the ILC heard a Special Rapporteur report, Dire Tladi, on the implications and legal impact of mandatory international law (jus cogens). The ILC 
took as a basis to analyze the essence of the notion of jus cogens the definition of general international law imperative rules contained in Art. 53 of the VCLT: A treaty is invalid if when it is concluded it contradicts an imperative general international law - jus cogens. Based on Diré Tlady's analysis, Draft Conclusion № 10 identified the grounds for a treaty's invalidity that contradicts a mandatory rule of general international law (jus cogens):

a) A treaty is invalid if, when it is concluded, it contradicts a mandatory rule of general international law (jus cogens).

b) An existing treaty shall become invalid. It shall cease to have effect if it contradicts a mandatory rule of general international law (jus cogens) that arises after the treaty conclusion.

c) To avoid a conflict with a universally binding rule of international law, the treaty provisions should be interpreted for it to become compatible with the mandatory rule of general international law (jus cogens).

The ILC also identified in Conclusion № 11 cases of conflict and mechanisms for their elimination between the provisions of an international treaty and an imperative norm (jus cogens), noting in paragraph 2 the following:

A treaty, becoming invalid as a consequence of the formation of a new mandatory rule of general international law (jus cogens) shall be terminated in its entirety, except in cases when:

a) provisions, contradicting the mandatory rule of general international law (jus cogens), in terms of application are distinct from the rest of the treaty;

b) provisions that are in violation of a mandatory rule of general international law (jus cogens) do not constitute a significant basis for a treaty-making agreement;

c) further performance of the rest of the treaty would not be unfair.

The jus cogens concept is mentioned in the decisions of the ICJ on the Continental Shelf of the North Sea in 1969 and on military and paramilitary operations (Nicaragua v. USA) in 1986, in the Decisions on armed activities in the Congo (DR Congo v. Rwanda) 2006, in the document on the Application of the Convention on the Prevention and Punishment of the Crime of Genocide, 2007, in the document on the Obligation to Prosecute and Extradite (Belgium v. Senegal) (2012).

Jus cogens is a mandatory international law notion from the time it was created until it was included into the VCLT, although its concept, nature and content remain the subject of heated debate (Butkevych: 2015, 207-218). This is explained by the fact that neither the criteria according to which certain international law rules could be referred to this category, nor, moreover, the list of mandatory rules the VCLT did not 
propose. The substantive coverage of jus cogens is limited. The prohibition of aggression, human trafficking, torture, genocide, apartheid, racial discrimination, rules and humanitarian law principles, the right to self-determination, and others do not objectively constitute a system that encompasses all other international law principles and rules. The UN Security Council has repeatedly addressed the issue of jus cogens, but, unfortunately, during all the years of its activity, a detailed concept on this issue of international law has not been formed. For a long time, the doctrine of jus cogens norms remained only the subject of scientific research, without manifesting itself either in international documents or in international practice.

Examples of the vagueness of jus cogens' nature include the Jurisdictional Immunities of the State case. In resolving the dispute between Germany and Italy, the ICJ did not support Italy's argument that Germany's rules on jurisdiction immunity of other states' courts should not be applied. This was argued by the fact that these rules contradicted the norms of jus cogens, which, according to Italy, were enshrined in the Geneva Conventions (it referred to Germany's responsibility for crimes committed in Italy by the Nazis during World War II) (ICJ Reports. Judgment (3 February 2012), 92-95).

However, the emergence of an imperative concept, namely jus cogens, aims to make changes in the international legal order in the context of equality of states, in the sense that states must respect this rule. Today, the concept of jus cogens, reflected in Art. 53 of the VCLT as a rule of international customary law is generally accepted, although rarely used in public practice.

The jus cogens were first mentioned in 1986 by the International Court of Justice in its judgment in Nicaragua v. United States case, referring to UN Commission on International Law provisions that UN Charter provisions, prohibiting the use of force, are obvious example rules of international law with the nature of jus cogens (ICJ Reports. Judgment. Nicaragua v. United States of America). In 2002, the ICJ in another decision recognized the prohibition of genocide as the jus cogens rule (ICJ Reports. Judgment. Democratic Republic of the Congo v. Rwanda). 6, 32). In 2001, the prohibition of torture was recognized by the ECtHR in its Al-Adsani judgment as a jus cogens norm. (ECHR. Paras 34, 55).

H. J. Fitzmaurice, Lauterpach's successor, presented jus cogens in the context of his concept of "substantial validity," which sought to assess the treaty's validity. J. Fitzmaurice distinguished between the legality and morality of a treaty by defining a valid treaty as one whose content corresponds to or does not contradict the principles and rules of international law and is endowed with the jus cogens nature. Particularly, a treaty is void if its subject matter or performance provides for: a) a violation of the principles of the United Nations Charter; $b$ ) any act or inaction that 
is characterized by international law as an international crime; or c) any act or inaction of repression or punishment, each of which necessitates international law's cooperation. The provisions of this Article, on the other hand, do not apply to a general multilateral treaty repealing or amending ajus cogens rule (Dörr, Schmalenbach: 2018, 958).

The Vienna Conference of 1969 supported the incorporation of a jus cogens provision. But the point of debate is the nature of jus cogens endowed with various actions - support for international peace, non-aggression, noninterference in the internal affairs of the state, sovereign equality of states, selfdetermination and the prohibition of trafficking, slavery, threat or use of force, genocide, forced labor, piracy, and racial discrimination, etc.

Analysing Art. 53 of the VCLT, Canadian professor of international law Michael Byers emphasizes signs of a positivist approach to its formation, arguing that customary international law rules acquire imperative status as a result of the state's confirmed consent. Although even among the positivist vision supporters, the author notes, there is an opinion that jus cogens goes beyond the usual interstate lawmaking (Byers: 1997, 66, (2, 220, 222). Jus cogens is an authorized means for the global community to help avoid regulatory fragmentation of public international law because it is neutral to private values and needs although not to the interests of the public (utilitas publica) (Kolb: 2015, 49).

The theory of E. Criddle and E. Fox-Decent, which claimed that states must adhere to imperative rules as the primary human dignity guarantees through the state sovereignty compliance, aims to explain jus cogens rules' imperative status (Criddle, Fox-Decent: 2009, 387). T. Weatherall's approach is also based on a socioanthropologically focused understanding of jus cogens, such as that the global community of states fulfills mankind's shared human needs in accordance with mankind's interests and values (Weatherall: 2015, 444).

\section{The issue of global community consensus on jus cogens}

The jus cogens notion reflects the requirement of universality, given that the wording of Article 53 links mandatory rules with the approval of the "global community of states" as a whole. Taking the form of jus cogens, the global community of states itself is interested in the presence of customary rules and their adherence (ICJ Reports. Judgment (Nicaragua v. United States of America, Para 190).

General principles of law are an international law source and have the status of jus cogens. In terms of general international law, Art. 53 of the VCLT expressly 
excludes any obligation with regard to a specific international law source, particularly those listed in subparagraph 1 of Art. 38 of the ICJ's Statute.

In the meantime, according to the VCLT, the global community of states is endowed with a de facto law-making function, and the consensus of the components of this community of states, according to some researchers, should be considered as an autonomous international law source. This peculiarity of the global community may be caused by a specific of jus cogens rules, the formation of which differs significantly from the formation of other international law rules

While focusing on universal practice, the ICJ expressly dismisses the idea of jus cogens as an autonomous international law source. In the case of bringing to trial or extradition, the prohibition of torture, according to the Court, is a part of customary international law and has become a compulsory rule (jus cogens). This prohibition is based on extensive international practice and states opinion juris. It appears in a number of international documents... > and is incorporated into almost every state's national legislation. (ICJ Reports. Judgment (20 Juli 2012. Belgium v. Senegal).

Article 53 of the VCLT defines mandatory rules as rules from which deviation is not allowed: Ignoring the prohibition renders the treaty void and subjects all parties to the void contract to liability.

Despite the fact that Art. 53's purpose is to protect international law's fundamental rules, no legal sanction is provided (Linderfalk: 2011, 377). However, the process of modification is complicated by the requirement that the forthcoming rule to change the jus cogens should have an analogical character. It should be noted that the rule of modification, foreseen by the Art. 53, causes significant problems: unconditional customary norms are never allowed (e.g., the right to exercise jurisdiction); they are rarely mandatory (e.g., a command to liberate people from colonial rule), but are mostly prescriptive (e.g., the prohibition of coercion or inhuman behavior). As a result, rules that alter established imperative norms either broaden or narrow the scope of the prohibition or the obligation to act. The debate over humanitarian intervention as an exception to the use of force ban suggests that the "eternal" jus cogens extends beyond international realities. It is necessary to take into account the practical solution of this conflict: Art. 53's requirement for a replacement can be interpreted as the conclusion that jus cogens is subject to revision if the global community as a whole accepts it.

Art. 53 of the VCLT describes the procedure concerning jus cogens. The phrase "accepted and recognized by the global community as a whole" is commonly interpreted as implying that the VCLT is founded on a positivist understanding of jus cogens. 
On the flip side, a multilateral treaty can quickly debunk the myth that the global community of states as a whole predicates the nature of jus cogens to customary rules reflecting basic treaty provisions. Suppose a multilateral treaty makes it possible for Parties to unilaterally withdraw from it. In that case, definitive proof is required to support the conclusion that the global community as a whole disallows the abolition of its analog.

General principles of law are the basis for creating jus cogens, as a minimum for any who denies the unambiguity of the positivist comprehension of Art. 53, thanks to their "natural-legal character." General principles of law recognized in national legislation cannot be considered unappealable in view of Art. 53 simply because they are recognized by most national legal systems. Contrastingly, the rules of jus cogens are derived from the core values to which the global community adheres, bind the entire global community without regard to objections.

Today, more than 50 years after the VCLT conclusion, the notion of jus cogens is not disputed. Constant objections' inadmissibility to customary laws, commonly acknowledged as jus cogens, explains by the fact that, as stipulated in Art. 53, an unappealable customary international law rule is a rule accepted and recognized by the global community. As all respective statesparticipants with these two essential preconditions of jus cogens, they refused to deny the global community's consensus on jus cogens permanently. It goes without saying that at the present stage of solving the problem of jus cogens rules, it is more expedient to start not so much with the substantiation of their imperative, but with the definition of a specific goal, the achievement of which is possible as a result of the jus cogens concept. This is not about general goals, such as "maintaining peace", "security of the global community", etc. For such purposes, the search for new approaches to jus cogens' norms is simply unnecessary. It is about the practical significance in the context of new challenges and threats, which the global community have not yet been encountered, justifying the need to develop the concept of jus cogens further and create the conditions for its progressive development (Dörr, Schmalenbach, 2018). The most significant practical interest attracts grounds for their classification as such but in Art. 53 they are not defined.

\section{Interpretation as a way to resolve the conflict between treaty provisions and jus cogens}

Whenever a party to two agreements is unable to fulfill its obligations under both agreements at the same time, a regulatory conflict occurs. In other 
words, there is a normative conflict when the operation of one rule interferes with the function of another. A normative conflict arises when a treaty provision either permits or prohibits actions defined by jus cogens. (Orakhelashvili: 2006, 138).

Application of Art. 31 to both rules should resolve the problem if a normative conflict between treaty provisions and jus cogens exists. In its decision in the Al-Adsani case, for example, the ECtHR stated:

Despite the unique nature of the international law prohibition on torture, the ECtHR cannot find grounds in available international documents, judicial bodies, or other law sources to conclude that, as a matter of international law, a State no more has immunity from civil action in the judicial system of other nations where torture acts are envisaged (ECHR. Para 61).

In the event of a normative conflict between treaty provisions and jus cogens, the treaty - not just the provisions that contradict jus cogens - is invalid under Art. 53 in conjunction with paragraph 5 of Art. 44. A treaty's invalidity is absolute, which means that the treaty does not operate at the international level for both the participants and other international actors.

Jus cogens is the highest rule in a legal hierarchy. In the global community's interests, the prohibition on derogations from jus cogens prohibits any conflicting legal acts or situations. In the Genocide Case (1993), for example, ICJ Judge H. Lauterpacht stated that "the concept of jus cogens operates as a concept that transcends both customary international law and the treaty."

Predicated on the belief that civilized peoples recognize general principles of law (Article 38 (1) (c) of the ICJ Statute), the normative conflict between general principles and jus cogens indicates sharp methodological issues. A normative conflict between a unilateral act with legal consequences and jus cogens is logically impossible but not uncommon. In its Consultative Opinion on Kosovo's Declaration of Independence (2010), the International Court of Justice examined the Security Council's practice of condemning unilateral declarations of independence and reached a conclusion: the illegality related to independence declarations stems not from their unilateral nature but from the fact that they were or would be related to the unlawful use of force or violations of general international law, particularly those with imperative character (jus cogens) (ICJ Reports. Para 81). A unilateral act is null and void in the event of normative conflict and thus cannot be used by the declaring body, the state, or any other states.

At the Seventieth Session of UNGA (April 30 - June 1 and July 2 - August 
10, 2018) in the Concluding Observations of the ILC Dire Tladi shared the opinion of the Commission members on the importance of properly presenting the implications of jus cogens for the international legal system strength. He confirmed that the topic's purpose is not to develop new rules, but to make existing rules more accessible and understandable. Mister Tladi emphasized that the Commission's task was to accurately assess practice, along with other sources normally relied on by the Commission, in order to achieve the most accurate description of existing international law. It is important to note, that many of the draft conclusions proposed by him contain wording taken from the VCLT, although the latter's structure was developed taking into account not only jus cogens rules.

With regard to the proposed draft opinions, Dire Tladi supported the proposal to create a single draft conclusion containing a general rule of interpretation to apply to all sources of international law. Such a rule must comply with interpretation rules stipulated by the VCLT. It was also emphasized that the main principle for such an interpretation should be honesty. The pacta sunt servanda principle is one of essential factors for the application of a thorough and consistent approach to treaties interpretation, and, if possible in accordance with jus cogens, such an approach will always be more effective than the termination of the treaty (UNGA (2018). Seventy Session).

Alternatively, the may become legally binding as customary international law rules perceived as such by non-participating parties (Article 38 of the VCLY). In this light, the global community perceives this definition: it emerges from the common practice of states, international judicial bodies, and special academic literature. As Thomas Weatherall noted, although the VCLT deals with the law of treaties and is binding only for signatories, $<\ldots>$ Art. 53 became a reflection of the concept according to which the legal action goes beyond the contractual context (Weatheral, 2015: 6).

Consideration of the cases by the ICJ is carried out in strict compliance with the standards of jus cogens, which are prescribed in the VCLT as the basis of the mechanism of their recognition, as well as good faith principles and giving the terms their usual meaning. Thus, in a dissenting opinion of Judge Nabil Elaraby in the case of Serbia and Montenegro v. Belgium on the legality of the use of force and genocide in interpreting the phrase "existing treaties" was expressed the intention to consider peace agreements after World War II as a settlement, and also as elimination of violations of the contractual jus cogens rules (Separate opinion of Judge Elaraby. (9 Juli 2004). A point was made that, in the light of the UN Charter, the 1948 Convention on the Prevention and Punishment of the Crime of Genocide can be considered a peace treaty because it was adopted soon after the war's end; it prohibited genocide as a crime against 
international law; and it was the first postwar human rights treaty that actually meant "correcting violations" of jus cogens.

In Commission`s Report on International Law during its 70th Session (item 82 of the Agenda, continuation) (A / 73/10), Madame Hiureas (Cyprus), referring to the topic "Imperative norms of general international law (jus cogens)" in the light of the law of treaties, noted that treaties should be interpreted in a format compatible with mandatory rules. Indeed, prior to the adoption of the draft articles of the Commission on the Law of Treaties and the VCLT, many states, including Cyprus, invoked jus cogens. The ILC stressed that in the context of the provisions of Art. 53 of the VCLT, it is essential to examine the possible annulment of the binding force of a jus cogens rule, the determination of who defines whether a treaty contradicts the rule (regulatory conflict), and the possible legal consequences of a potential (possible) interpretative conflict. The ILC also recommended avoiding any decisions that could lead to any deviation from the Convention, or ones to be interpreted as such.

\section{CONCLUSIONS}

Hence a paradox exists - jus cogens notion in international law is generally accepted, there is a normatively established definition of such a rule, but its specific framework and content remain uncertain: there is no list or clear criteria by which a rule can be classified as mandatory. The ICJ has repeatedly examined the notion of jus cogens rules, but has not developed a detailed concept on this issue.

The problem of establishing jus cogens is difficult to solve in abstractio. The reason lies not only in the absence of a single official list of jus cogens rules - the criteria for including rules in such a list are not defined. Opinions of representatives of the doctrine and the international judiciary on this issue differ significantly. In particular, one proposes to consider as jus cogens rules all or most of the general international humanitarian law rules and pacta sund servanda principle.

The considerations presented in this research show a special, if not decisive, role in jus cogens 'observance by national and international courts. However, the main threat to jus cogens doctrine itself is judges' tendency to see these norms everywhere, without properly examining the extent to which they are agreed by the global community. Regarding the role and significance of jus cogens or general international law imperative rules, in the adherence and interpretation of treaties, it goes without saying that treaties are to be interpreted in a manner compatible with imperative norms. 


\section{REFERENCES:}

Bossuyt, M., \& Wouters, J., (2005). Grondlijnen van intemationaal recht. Antwerpen: Intersentia.

Butkevych, O. B. (2006). Formation of jus cogens norms in pre-classical international law. Bulletin of the Academy of Legal Sciences. 4, 207-218.

Byers, M. (1997). Conceptualising the Relationship between jus cogens and erga omnes Rules. Nordic Journal of International Law. 66 (2), 211-239.

Criddle, E. J., Fox-Decent, E. (2009). A Fiduciary Theory of jus cogens. Yale Journal of International Law. 34 (2). $1.43-447$. Retrieved from: https://onlinelibrary.wiley.com/doi/abs/10.1111/j.1750-0206.2004.tb00510.x

Dörr, O., Schmalenbach, K. (eds.). (2018). Vienna Convention on the Law of Treaties: A Commentary. 2nd ed. Berlin: Springer, LVIII.

European Court of Human Rights. (21 November 2001). Case of Al-Adsani v. the United Kingdom (Applicatiom no. 35763/97). Judgment. Strasbourg. Paras 34, 55,61 .

Grushko M. V. (2018). War crimes as international crimes jus cogens military crimes as an international jus cogens. Actual problems of domestic jurisprudence. 1, 241244.

ICJ Reports. (13 September 1993). Separate opinion of Judge Lauterpacht. Case Concerning Application of the Convention on the Prevention and Punishment of the Crime of Genocide (Bosnia and Herzegovina v. Serbia and Montenegro). Para 100.

ICJ Reports. Advisory Opinion. (22 juli 2010). Accordance with International Law of the Unilateral Declaration of Independence in Respect of Kosovo. Para 81.

ICJ Reports. Judgment (20 Juli 2012). Questions Relating to the Obligation to Prosecute or Extradite (Belgium v. Senegal). Para 99.

ICJ Reports. Judgment (27 June 1986). Case concerning Military and Paramilitary Activities in and Against Nicaragua (Nicaragua v. United States of America). Merits. Para 190.

ICJ Reports. Judgment (3 February 2006). Case concerning Armed Activities on the Territory of the Congo (Democratic Republic of the Congo v. Rwanda). Jurisdiction of the Court and Admissibility of the Application 6, 32.

ICJ Reports. Judgment (3 February 2012). Jurisdictional Immunities of the State (Germany v. Italy: Greece Intervening), 92-95. 
ICJ Reports. Separate opinion of Judge Elaraby. (9 Juli 2004). Retrieved from: https://www.icj-cij.org/files/case-related/105/105-20041215-JUD-01-01-EN.pdf

Kolb, R. (2015). Peremptory International Law - jus cogens: A General Inventory. Oxford. Portland: Hart Publisher.

Lauterpach, H. (1958). The development of International Law by the International Court. London: Stevens.

Linderfalk, U. (2011). The Creation of Jus Cogens - Making Sense of Article 53 of the Vienna Convention. Zeitschrift für ausländisches öffentliches Recht und Völkerrecht. 71, 359-378.

Mosler, H. (1974). International Society as a Legal Community. Recueil des Cours de l'Académie de Droit International de La Haye. 140 (1), 11-14.

Multilateral Vienna Convention on the law of treaties (with annex). Concluded at Vienna on 23 May 1969.

Orakhelashvili A. (2006) Peremptory Norms in International Law. Oxford: Oxford University Press.

United Nation. (1951). Convention on the Prevention and Punishment of the Crime of Genocide. Adopted by the General Assembly of the United Nation on 9 December 1948. No. 1021 / Treaty Series.

United Nations. (2018). General Assembly. Official Records. Seventy-third session. Report of the International Law Commission. Seventy Session (30 April1 June and 2 July-10 August 2018). Supplement No. 10 (A/73/10). New York.

United Nations. General Assembly. Seventy-third session. Official reports. (19 November 2018). 18-17950X (R). Sixth Committee Summary Report of the 25th Meeting (New York) Retrieved from: https://www.un.org/en/ga/sixth/73/ilc.shtml

Weatherall, T. (2015). Jus Cogens: International Law and Social Contract. Cambridge: Cambridge University Press.

Zadorozhniy, O.V. (2015). Normative protection of the principle of conscientious fulfillment of international obligations in modern international law. Law and society. 4. (4.) 12-21. 